\title{
Under Surveillance and Overwrought: American Muslims' Emotional and Behavioral Responses to Government Surveillance
}

\author{
Alexander J. O’Connor
}

Farhana Jahan

University of California, Berkeley

\section{Abstract}

After the 9/11 attacks, various United States law enforcement and intelligence agencies increased their monitoring and surveillance of American Muslims. We assessed the prevalence of such experiences with a sample of American Muslims. One-fifth of participants reported personal experiences with government surveillance. Relative to those not monitored, American Muslims who reported being monitored also reported being more anxious-but not more angry- about the prospect of government surveillance. Additionally, those monitored reported being more likely to modify their behaviors, avoiding contexts that might lead to government suspicion and future surveillance. Anxieties over the prospect of surveillance mediated the relationship between being previously monitored and modifying their behaviors. Parallels between these findings and literature on social identity threat and emotion regulation are discussed.

Keywords: American Muslims, profiling, anxiety, social identity threat, emotion regulation

Correspondence concerning this article should be addressed to Alexander O'Connor, Hitotsubashi University - ICS, 2-1-2 Hitotsubashi, Chiyoda-ku, Tokyo 101-8439, Japan. Email: aoconnor@ics.hit-u.ac.jp 
In early 2012, it was uncovered that the New York Police Department established an extensive program of surveillance and infiltration of Muslim student organizations in universities across the northeast (Ebadolahi, 2012). That this surveillance occurred both within and outside of New York City-in Connecticut and Pennsylvania, for instance-was early evidence of the extent and support of covert surveillance of American Muslims by United States law enforcement and intelligence agencies. Similar instances of widespread surveillance conducted by the Federal Bureau of Investigation (FBI) were later uncovered in other areas of the country (ACLU, 2012). Such reports of governmental surveillance, profiling, and monitoring-all which we consider in the present study-increased after September $11^{\text {th }}, 2001$ (Ibish, 2003). The USA PATRIOT Act (2001), signed in the months after 9/11, by reducing restrictions in law enforcement agencies' ability to conduct surveillance on anyone suspected of involvement in terrorism, provided the legal legitimacy for much of the subsequent surveillance (Council on American-Islamic Relations, 2004; Ibish, 2003). Revelations about the National Security Agency's surveillance program suggest that these methods have since expanded (Greenwald \& MacAskill, 2013). Such surveillance, however, has targeted many people, Muslims in particular, with no connection to terrorism (Ibish, 2003). Alongside other forms of post-9/11 discrimination experienced by American Muslims, government surveillance is associated with psychological distress-including depression and subclinical forms of paranoia (Ahmed, Kia-Keating, \& Tsai, 2011; Amer \& Hovey, 2012; Rippy \& Newman, 2006). Little is known, however, about (1) American Muslims' emotional reaction to being monitored by the government and (2) how they respond to, manage, and regulate these emotions alongside the prospect of continuing or future surveillance. The present work examined these two phenomena.

\section{American Muslims' Emotional Response to Government Surveillance}

Work by political scientists finds two dominant emotion responses-anxiety and anger-when people imagine being monitored by the government (Best \& Krueger, 2011). The emotional response of people personally experiencing government surveillance is, however, unknown. In the case of American Muslims experiencing government surveillance, anxiety levels are likely particularly pronounced. Consider that American Muslims monitored by the government, even after they are cleared of suspicion, are in a precarious position. Given the covert nature of US government surveillance (ACLU, 2012; Ebadolahi, 2012), those previously monitored can never be certain that monitoring has ceased. Even when believing surveillance has ceased, they may view them- 
selves as likely targets of future surveillance. Anxiety, not anger, is the typical response to such feelings of uncertainty and uncontrollability in response to the prospect of negative events (Lerner \& Keltner, 2001). Furthermore, given evidence of higher levels of anxiety, depression, sub-clinical paranoia, and disidentification among American Muslims who report more general forms of religious discrimination (Ahmed et al., 2011; Amer \& Hovey, 2012; Rippy \& Newman, 2006), those with potentially interminable experiences with government surveillance may be especially prone to higher levels of anxiety.

\section{Regulation of Surveillance Induced Emotion}

How do American Muslims experiencing government surveillance regulate the anxiety and uncertainty of not knowing if and when surveillance ceased or will resume in the future? Anxiety can inhibit the sort of behaviors that originally elicited the anxiety (Lerner \& Keltner, 2001; Shapiro \& Neuberg, 2007; Steele, Spencer, \& Aronson, 2002), while increasing vigilance for situational cues that may signal further threat (Murphy, Steele, \& Gross, 2007). Evidence from several literatures on stigma and social identity threat demonstrates that avoiding behaviors, situations, or aspects of an identity can serve as a recourse to avoiding the threat of being stigmatized, discriminated against, or confirming a negative stereotype (Crocker, Major, \& Steele, 1998; Davies, Spencer, Quinn, \& Gerhardstein, 2002; Goffman, 1963; Pinel, 1999; Steele, 1997; Swim, Cohen, \& Hyers, 1998). For instance, African Americans under stereotype threat avoid expressing interest in activities stereotypically associated with their group (Steele \& Aronson, 1995). Such social identity threats also influence the regulation of emotions such as anxiety-with threat often facilitating strategies that avoid or suppress the cognitions and emotions associated with that threat (Johns, Inzlicht, \& Schmader, 2008).

Given the research described above, we predicted the following: Experiencing government surveillance will predict (1) higher self-reported anxiety about the prospect of future surveillance and (2) an increased vigilance around and avoidance of people, situations, behaviors, and topics that could serve as signals inviting further surveillance. It is particularly troubling to note that American Muslims, anxious over the threat of surveillance, may find themselves vigilant and cautious around Americans who are not Muslims and fellow American Muslims. While non-Muslims are a potential threat to the extent they are perceived as informants, settings frequented by fellow Muslims (e.g., Islamic settings such as mosque) may be perceived as contexts the government is more likely to monitor. Further, we tested whether anxiety over further surveillance mediates the relationship between experiences with surveillance and the avoidance of potentially signaling settings. Such mediation would support 
the view that social identity threats, when increasing anxiety, facilitate the use of avoidant behaviors and strategies (Johns et al., 2008; Miller \& Kaiser, 2001).

\section{Method}

\section{Participants}

One hundred fourteen self-identified American Muslims participated during the winter of 2011/2012. Four participants did not respond to an item assessing whether they had experience with government surveillance and were therefore excluded from all analyses, leaving 110 participants (71\% female). Ages ranged from 16 to 65 years $(M=24.38 ; S D=9.19 ; M d n=21)$. The racial/ethnic breakdown of the sample was as follows: Arab/Central Asian (46\%), South/ East Asian (27\%), Black (11\%), White (7\%), Multiethnic/Multiracial (5\%), and Other/unreported (4\%).

\section{Measures}

Experience with government surveillance. We assessed personal experiences with government surveillance with the following item: "I have personally had an encounter with government surveillance because of my Muslim identity." Response options were "yes," "no," or "decline to state."

Anxiety and anger in response to government surveillance. Anxiety and anger items were developed through pilot studies with UC-Berkeley American Muslim undergraduate students. These students provided lists of common situations where they experience negative emotion due to the prospect of government profiling and surveillance based on their Muslim identity. Items that (1) were invoked by multiple pilot study participants and (2) which referenced anxiety and/or anger over expressing one's Muslim identity or performing Islamic practices and behaviors were re-worded for use in the present study. Seven scenarios were retained using this method.

Two items were then generated for each scenario-one item referenced anxiety as the response to the scenario while an independent item referenced anger as the response to the scenario. For instance, "I feel anxiety about expressing my Muslim identity through my appearance (e.g., hijab, kufi, abaya, beard) in public settings because of the risk of being profiled by the government or law enforcement" and "I feel angry that expressing my Muslim identity through my appearance (e.g., hijab, kufi, abaya, beard) in public settings carries the risk of being profiled by the government or law enforcement." Before answering these 14 items, participants were prompted they would be reporting their "emotional experience in response to the possibility of government 
surveillance." They then made their ratings on the 14 items on a 1 (strongly disagree) to 7 (strongly agree) scale. Thus, seven items comprised an anxiety response index $(M=4.02, S D=1.51, \alpha=.88)$ and seven items comprised an anger response index $(M=4.99, S D=1.52, \alpha=.92)$.

Avoidant and vigilant behaviors. Examples of avoidant and vigilant behaviors were developed by the authors. These items attempted to capture the scenarios and people that American Muslims might avoid or act cautiously around out of anxiety that certain behaviors in these contexts, however innocuous, might elicit government surveillance. Five such items $(\alpha=.70)$ were developed. For instance, "I distance myself from the Muslim community because of anxiety over surveillance" and "I distance myself from non-Muslims because they may report me to law enforcement for perceived suspicious activity based on my religious identification." Participants were asked to respond to the items while thinking about "how you deal with and manage your emotions in response to the possibility of government surveillance." Ratings were made on a 1 (strongly disagree) to 7 (strongly agree) scale $(M=2.91 ; S D=1.15)$.

\section{Procedure}

A link directing participants to the survey was emailed to multiple UC-Berkeley Muslim Student Association listservs and was posted on social media sites by a director of the Council on American Islamic Relations (CAIR). The survey link was accompanied by a brief description of the study, noting the survey concerned "current methods of government surveillance on Muslim Americans." Recipients were asked to participate only if they identified as American Muslim. Due to the sensitivity of the questions, the questionnaire was designed with an emphasis on brevity and stressing anonymity in both the consent and debriefing materials.

\section{Results}

Twenty participants (18\%) reported personal experience with government surveillance, a percentage similar to that found with other American Muslim samples (Abu-Ras, \& Suárez, 2009; Rippy \& Newman, 2006). A multivariate analysis of variance (MANOVA) tested for differences between those reporting personal experience and those reporting no personal experience with government surveillance on the anxiety, anger, and avoidant/vigilance behavior modification scales. Participants who reported personal experience with government surveillance expressed more anxiety in response to surveillance $(M$ $=4.64, S D=1.33)$ than participants reporting no personal experience with government surveillance $(M=3.87, S D=1.50), F(1,108)=4.56, p=.04$ (Fig- 
Figure 1. Legend designates participants who report having and not having personal encounters with US government surveillance based on their Muslim identity. Error bars represent standard errors of the mean.

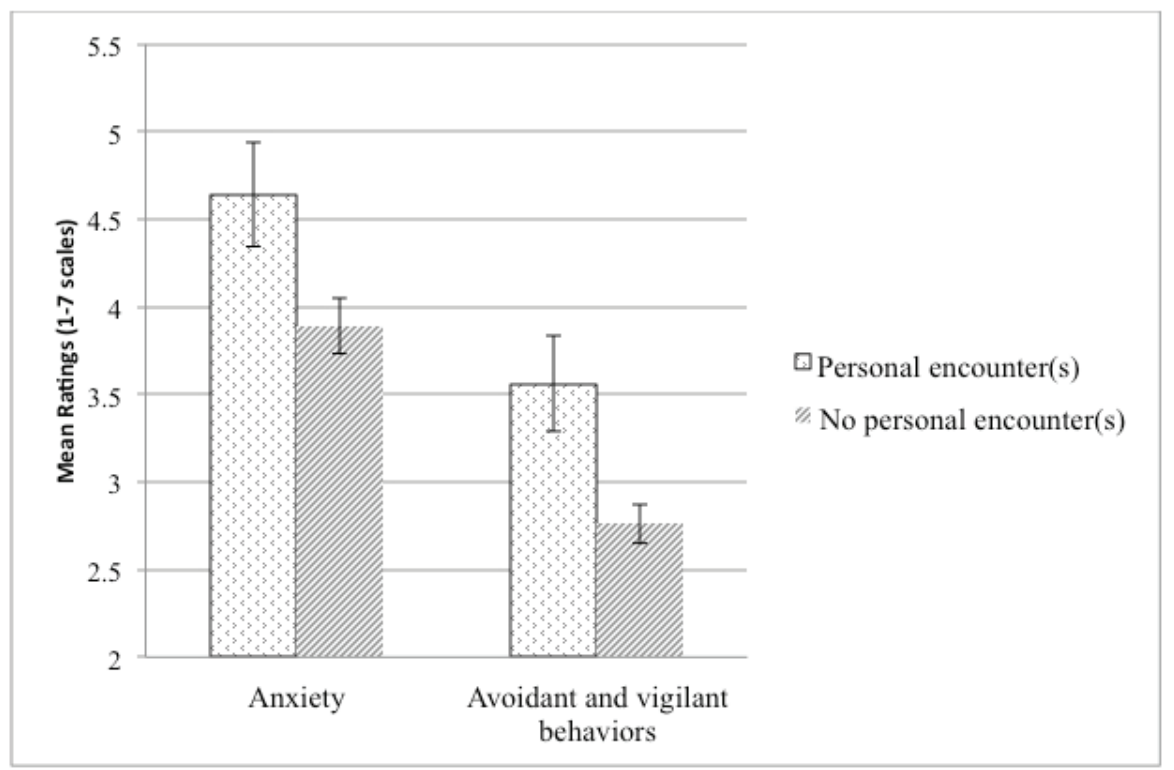

ure 1). Participants with and without personal experience with government surveillance, however, did not report different levels of anger in response to surveillance, $F(1,108)=1.27, p=.26$. Additionally, participants with personal experience with government surveillance reported adopting more avoidant and vigilant behaviors in response to the possibility of government surveillance $(M=3.56, S D=1.21)$ than participants with no personal experience with government surveillance $(M=2.76, S D=1.09), F(1,108)=8.35, p<.01$ (Figure 1).

We earlier proposed that participants who reported personal experience with government surveillance were more likely to modify their behaviors in response to the anxieties felt over the potential of future profiling. Because self-reported anxiety and avoidant and vigilant behaviors were significantly correlated, $r(110)=.64, p<.001$, we tested this possibility through a mediation model (Figure 2). We used bootstrapping procedures to compute confidence intervals around the proposed mediator (Preacher \& Hayes, 2004; Shrout \& Bolger, 2002). Muslim identification was included as a covariate in the model. This mediation model was significant, 95\% CIs [.0404, .3926]. This result suggests that American Muslims profiled and monitored by governmental agencies may increase their vigilance and avoid certain behaviors and people, in part, because of anxieties over the possibility of future profiling and surveillance. 
Figure 2. Mediational model with self-reported anxieties over the potential of future government surveillance mediating the link between being previously profiled and reporting avoidant and vigilant behaviors.

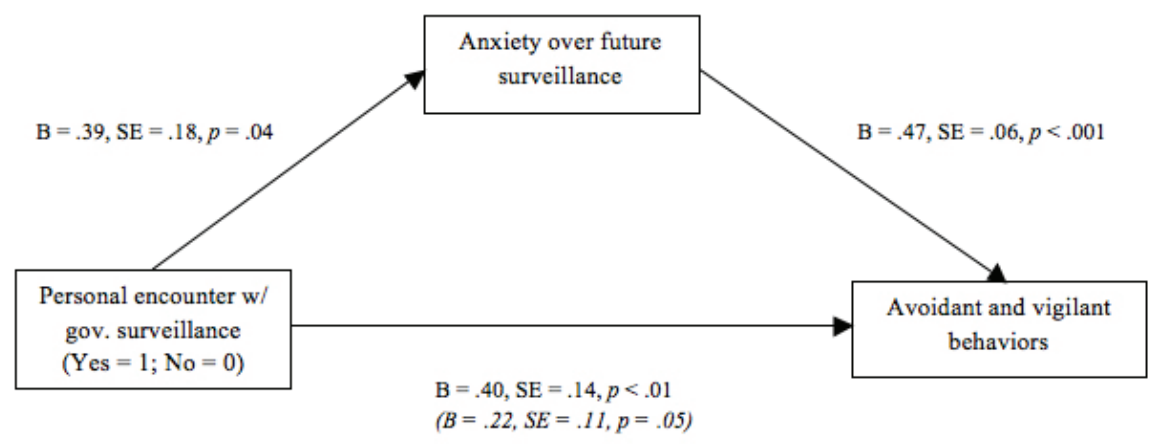

\section{Discussion}

The present study provides evidence that American Muslim's experiences with government surveillance are accompanied by increases in anxiety over future surveillance, avoidance discussing topics that may increase the possibility of surveillance, and avoidance of certain settings over concern it would lead to being reported to intelligence agencies. This result is in line with the increasing prevalence of anxiety and paranoia symptoms reported in American Muslims experiencing religious discrimination (Ahmed et al., 2011; Amer \& Hovey, 2012; Rippy \& Newman, 2006) and some of the more general work on stress and coping in response to state-sponsored persecution (Lustig et al., 2004). More broadly, it also fits within the social identity threat and stigma literatures, which highlight coping mechanisms stigmatized individuals utilize when confronted with discrimination and other social identity threats (Crocker et al., 1998; Miller \& Kaiser, 2001; Shapiro \& Neuberg, 2007).

Negative emotions-in particular, anxiety-are sometimes credited responsibility for the negative performance decrements associated with social identity (stereotype) threat (Shapiro \& Neuberg, 2007; Steele, 1997; Steele et al., 2002). More recent work demonstrates that beyond the experience of anxiety, the regulation of anxiety resulting from identity threat is taxing and detrimental as well (Johns et al., 2008; Schmader, Johns, \& Forbes, 2008). For the sample in this study, strategies that attempt to hide and minimize expressions of identity (and thus the suspicion of other people), may become preferred strategies. Specifically, situational avoidance and various forms of suppression (behavioral, cognitive, and emotional) may be effective at eluding the suspi- 
cion of others. However, these strategies can be cognitively and physiologically costly (Gross, 1998; Richards \& Gross, 2000; Wegner, 1994), may elicit rumination, and likely inhibits the disclosure of thoughts and feelings about the threat, which might otherwise prove beneficial (Major \& Gramzow, 1999; Pennebaker, Kiecolt-Glaser, \& Glaser, 1988). If the threat of being monitored by one's own government is realistic enough - and it is for those previously monitored-then avoiding future monitoring is likely a primary goal. But this puts American Muslims in a position of preferring coping strategies that may serve as a mechanism partly responsible for the high rates of psychological distress currently found in these communities (Ahmed et al., 2011; Amer \& Hovey, 2012; Rippy \& Newman, 2006).

\section{The Role of Anger}

It is important to note that while reports of anger were unrelated to reports of experience with surveillance, reports of anger were quite high. ${ }^{1}$ While not the focus of this research, anger likely triggers unique behavioral consequences. For instance, work by political scientists suggests that the prospect of government surveillance leads to political mobilization and participation, particularly within the American Muslim and Arab communities (Ayers \& Hofstetter, 2008; Cho, Gimpel, \& Wo, 2006). Best and Krueger (2011), who examined anger and anxiety in response to the presence and acknowledgement of government surveillance in a broad sample of Americans, found that anger, not anxiety, predicted political participation. Thus, anger, its regulation, and its behavioral correlates likely play a unique role in experiences with discrimination. But the persistent uncertainty associated with experiences of government surveillance may have an unique effect on anxiety, not anger.

\section{Limitations and Conclusions}

There is legitimate concern surrounding the reliability of any assessments of perceptions of government surveillance. Regarding self-reports in particular, group identification (Major, Gramzow, McCoy, Levin, Schmader, \& Sidanius, 2002; Operario \& Fiske, 2001; Sellers \& Shelton, 2003), stigma consciousness (Pinel, 1999), and group-based rejection sensitivity (Mendoza-Denton, Downey, Purdie, Davis, \& Pietrzak, 2002) all influence perceptions and reports of discrimination. Furthermore, the present study cannot distinguish between actual, perceived, and misperceived instances of surveillance. We must further consider that the majority of this sample was college-aged and recruited from Muslim community organizations. This latter point suggests our sample was more identified with being Muslim than may be typical within the United States. Since stronger group identification predicts increased perceptions 
of discrimination (Sellers \& Shelton, 2003), our data may not be an accurate reflection of the prevalence of perceived or reported surveillance. Because of the above factors, we caution against reading much into the descriptive result that about $20 \%$ of participants reported experience with government surveillance. While this percentage was similar to that previously reported (Abu-Ras \& Suárez, 2009; Rippy \& Newman, 2006), it is difficult to infer the actual incidence of US government use of surveillance on American Muslims, particularly from this sample.

Beyond considering the above factors, future research should distinguish between the many methods of government surveillance. For instance, certain forms of surveillance may become apparent in later stages (e.g., when they culminate in government questioning and interviewing), whereas other methods may be more widespread and less likely identified (e.g., monitoring of internet activities) and thus less likely to be reported. This study's reliance on a single item measure of perceived discrimination prevents examination of the above points. More elaborate assessments of perceived discrimination are necessary in future research to examine these distinctions and effects.

Nonetheless, the present study supports the idea that surveillance of American Muslims has potentially longstanding emotional and behavioral consequences-consequences that may cause the heightened levels of psychological distress found within this community (Ahmed et al., 2011; Amer \& Hovey, 2012; Rippy \& Newman, 2006). Because there is such widespread support for the expansion of federal powers in combating terrorism (Huddy \& Feldman, 2011), the risks that new policies pose to unintended victims can be easily overshadowed. This study seeks to highlight how some of these risk factors develop in American Muslims experiencing government surveillance. Such information is necessary in assessing the long-term and unintended consequences of government surveillance on segments of the American population.

\section{References}

Abu-Ras, W. M., \& Suárez, Z. E. (2009). Muslim men and women's perception of discrimination, hate crimes, and PTSD symptoms post 9/11. Traumatology, 15(3), 48-63. http://dx.doi.org/10.1177/1534765609342281

ACLU. (2012, March 27). ACLU EYE on the FBI [bulletin]. Retrieved from: http://www. aclu.org/files/assets/aclu_eye_on_the_fbi_-_mosque_outreach_03272012_0_0. pdf

Ahmed, S. R., Kia-Keating, M., \& Tsai, K. H. (2011). A structural model of racial discrimination, acculturative stress, and cultural resources among Arab American adolescents. American Journal of Community Psychology, 48, 181-192. http:// dx.doi.org/10.1007/s10464-011-9424-3

Amer, M. M., \& Hovey, J. D. (2012). Anxiety and depression in a post-September 11 
sample of Arabs in the USA. Social Psychiatry and Psychiatric Epidemiology, 47, 409-418. http://dx.doi.org/10.1007/s00127-011-0341-4

Ayers, J. W., \& Hofstetter, C. R. (2008). American Muslim political participation following 9/11: Religious belief, political resources, social structures, and political awareness. Politics and Religion, 1, 3-26. http://dx.doi.org/10.1017/S1755048308000023

Best, S. J., \& Krueger, B. S. (2011). Government monitoring and political participation in the United States: The distinct roles of anger and anxiety. American Politics Research, 39, 85-117. http://dx.doi.org/10.1177/1532673X10380848

Cho, W. K. T., Gimpel, J. G., \& Wu, T. (2006). Clarifying the role of SES in political participation: Policy threat and Arab American mobilization. The Journal of Politics, 68, 977-991. http://dx.doi.org/10.1111/j.1468-2508.2006.00484.x

Council on American-Islamic Relations. (2004). Unpatriotic Acts (Annual Report of the Status of Muslim Civil Rights in the United States). Washington, DC: Council on American-Islamic Relations Research Center.

Crocker, J., Major, B., \& Steele, C. M. (1998). Social stigma. In D. T. Gilbert, S. T. Fiske, \& G. Lindzey (Eds.), The handbook of social psychology (Vol. 2, 4th ed., pp. 504553). Boston: McGraw-Hill.

Davies, P. G., Spencer, S. J., Quinn, D. M., \& Gerhardstein, R. (2002). Consuming images: How television commercials that elicit stereotype threat can restrain women academically and professionally. Personality and Social Psychology Bulletin, 28, 1615-1628. http://dx.doi.org/10.1177/014616702237644

Ebadolahi, M. (2012, February 24). Associated Press Report Confirms Widespread Secret NYPD Surveillance of Innocent Muslims. ACLU National Security Project. Retrieved from http://www.aclu.org/blog/national-security-religion-belief/ associated-press-report-confirms-widespread-secret-nypd

Greenwald, G., \& MacAskill, E. (2013, June 6). NSA Prism program taps in to user data of Apple, Google and others. The Guardian. Retrieved from http://www.theguardian.com/world/2013/jun/06/us-tech-giants-nsa-data

Gross, J. J. (1998). Antecedent- and response-focused emotion regulation: Divergent consequences for experience, expression, and physiology. Journal of Personality and Social Psychology, 74, 224-237. http://dx.doi.org/10.1037/0022-3514.74.1.224

Huddy, L., \& Feldman, S. (2011). Americans respond politically to 9/11: Understanding the impact of the terrorist attacks and their aftermath. American Psychologist, 66, 455-467. http://dx.doi.org/10.1037/a0024894

Ibish, I. (2003). Report on hate crimes and discrimination against Arab Americans: The post September 11 backlash, September 11, 2001-October 11, 2002. Washington, DC: American-Arab Anti-Discrimination Committee.

Johns, M., Inzlicht, M., \& Schmader, T. (2008). Stereotype threat and executive resource depletion: Examining the influence of emotion regulation. Journal of Experimental Psychology: General, 137, 691-705. http://dx.doi.org/10.1037/a0013834

Lerner, J. S., \& Keltner, D. (2001). Fear, anger, and risk. Journal of Personality and Social Psychology, 81, 146-159. http://dx.doi.org/10.1037/0022-3514.81.1.146

Lustig, S. L., Kia-Keating, M., Knight, W. G., Geltman, P., Ellis, H., Kinzie, J. D., et al. (2004). Review of child and adolescent refugee mental health. Journal of the American Academy of Child \& Adolescent Psychiatry, 43, 24-36. http://dx.doi. org/10.1097/00004583-200401000-00012

Major, B., \& Gramzow, R. H. (1999). Abortion as stigma: Cognitive and emotional implications of concealment. Journal of Personality and Social Psychology, 77, 735745. http://dx.doi.org/10.1037/0022-3514.77.4.735 
Major, B., Gramzow, R. H., McCoy, S. K., Levin, S., Schmader, T., \& Sidanius, J. (2002). Perceiving personal discrimination: The role of group status and legitimizing ideology. Journal of Personality and Social Psychology. 82, 269-282. http://dx.doi. org/10.1037/0022-3514.82.3.269

Mendoza-Denton, R., Downey, G., Purdie, V. J., Davis, A., \& Pietrzak, J. (2002). Sensitivity to status-based rejection: Implications for African American students' college experience. Journal of Personality and Social Psychology, 83, 896-918. http:// dx.doi.org/10.1037/0022-3514.83.4.896

Miller, C. T., \& Kaiser, C. R. (2001). A theoretical perspective on coping with stigma. Journal of Social Issues, 57, 73-92. http://dx.doi.org/10.1111/0022-4537.00202

Murphy, M. C., Steele, C. M., \& Gross, J. J. (2007). Signaling threat: How situational cues affect women in math, science, and engineering settings. Psychological Science, 18, 879-885. http://dx.doi.org/10.1111/j.1467-9280.2007.01995.x

Pennebaker, J. W., Kiecolt-Glaser, J., \& Glaser, R. (1988). Disclosure of traumas and immune function: Health implications for psychotherapy. Journal of Consulting and Clinical Psychology, 56, 239-245. http://dx.doi.org/10.1037/0022-006X.56.2.239

Pinel, E. C. (1999). Stigma consciousness: The psychological legacy of social stereotypes. Journal of Personality and Social Psychology, 76,114-128. http://dx.doi. org/10.1037/0022-3514.76.1.114

Preacher, K. J., \& Hayes, A. F. (2004). SPSS and SAS procedures for estimating indirect effects in simple mediation models. Behavior Research Methods, Instruments, \& Computers, 36, 717-731. http://dx.doi.org/10.3758/BF03206553

Richards, J. M., \& Gross, J. J. (2000). Emotion regulation and memory: The cognitive costs of keeping one's cool. Journal of Personality and Social Psychology, 79, 410-424. http://dx.doi.org/10.1037/0022-3514.79.3.410

Rippy, A. E., \& Newman, E. (2006). Perceived religious discrimination and its relationship to anxiety and paranoia among Muslim Americans. Journal of Muslim Mental Health, 1, 5-20. http://dx.doi.org/10.1080/15564900600654351

Schmader, T. , Johns, M., \& Forbes, C. (2008). An integrated process model of stereotype threat effects on performance. Psychological Review, 115, 336-356. http:// dx.doi.org/10.1037/0033-295X.115.2.336

Sellers, R. M. \& Shelton, J. N. (2003). The role of racial identity in perceived racial discrimination. Journal of Personality and Social Psychology, 84, 1079-1092. http:// dx.doi.org/10.1037/0022-3514.84.5.1079

Shapiro, J. R., \& Neuberg, S. L. (2007). From stereotype threat to stereotype threats: Implications of a multi-threat framework for causes, moderators, mediators, consequences, and interventions. Personality and Social Psychology Review, 11, 107-130. http://dx.doi.org/10.1177/1088868306294790

Shrout, P. E., \& Bolger, N. (2002). Mediation in experimental and nonexperimental studies: New procedures and recommendations. Psychological Methods, 7, 422445. http://dx.doi.org/10.1037/1082-989X.7.4.422

Steele, C. M. (1997) A threat in the air: How stereotypes shape intellectual identity and performance. American Psychologist, 52, 613-629. http://dx.doi.org/10.1037/0003066X.52.6.613

Steele, C. M., \& Aronson, J. (1995). Stereotype threat and the intellectual test performance of African Americans. Journal of Personality and Social Psychology, 69, 797-811. http://dx.doi.org/10.1037/0022-3514.69.5.797

Steele, C. M., Spencer, S. J., \& Aronson, J. (2002). Contending with group image: The psychology of stereotype and social identity threat. In M. P. Zanna (Ed.), Advances 
in experimental social psychology (Vol. 34, pp. 379-440). San Diego, CA: Academic Press.

Swim, J. K., Cohen, L. L., \& Hyers, L. L. (1998). Experiencing everyday prejudice and discrimination. In J. K. Swim \& C. Stangor (Eds.), Prejudice: The target's perspective (pp. 37-60). San Diego, CA: Academic Press. http://dx.doi.org/10.1016/B978012679130-3/50037-5

USA PATRIOT Act (U.S. H.R. 3162, Public Law 107-56), Title II, Sec. 218.

Wegner, D. M. (1994). Ironic processes of mental control. Psychological Review, 101, 34-52. http://dx.doi.org/10.1037/0033-295X.101.1.34

\section{Endnote}

1. Mean reports of anger $(M=4.99, S D=1.52)$ were above the mid-point of the scale and, across the full sample, were higher than reports of anxiety, $t(109)=-6.57$, $p<.001$. Supporting Best and Krueger (2011), anger may be the prominent emotion in response to envisioning and acknowledging government surveillance. The present study suggests that anxiety becomes particularly relevant after personal experiences with government surveillance. 